\title{
Using the Portfolio Approach to Assess Multi-year Engineering Projects: a Case Study
}

\section{Dr. Harold R Underwood, Messiah College}

Dr. Underwood received his Ph.D. in Electrical Engineering at UIUC in 1989, and has been a faculty member of the Engineering Department at Messiah College since 1992. Besides teaching Circuit Analysis, Electromagnetics, and Communications Systems, he supervises students on projects in the Integrated Projects Curriculum (IPC) and within the Communications Technology Group of the Messiah College Collaboratory. His on-going projects include Flight Tracking and Messaging for small planes in remote locations, and assistive communication technology involving Wireless Enabled Remote Co-presence for cognitively and behaviorally challenged individuals. 


\section{Using the Portfolio Approach to Assess Multi-year Engineering Projects: A Case Study}

Meeting the needs of service learning project clients often requires more extensive treatment than a student team can provide in a single academic year. We find that a multi-year undergraduate engineering project curriculum improves on the traditional senior capstone course by extending the time period over which such credited treatment occurs, while offering additional benefits. Among the added benefits is increased project continuity, as senior students pass on knowledge, expertise and progress to junior students, sustaining project work in service of the client over multiple academic cycles. While clients and faculty enjoy project continuity and longevity, the multi-year project plan benefits students by increased opportunities for management and leadership, making the educational experience a more complete and realistic one. Coyle, et al. has presented the EPICS model for a multi-year engineering project program with multidisciplinary and service-oriented emphases, as implemented at a large university. ${ }^{1}$ We have implemented a similar multi-year plan known as the Integrated Projects Curriculum (IPC), that functions effectively for our smaller engineering program at Messiah College. Evaluating multi-year project work in various phases of development entails unique challenges as compared to the traditional capstone approach, but using a portfolio to assess the ongoing project work serves as a practical and effective tool, with sufficient flexibility. The portfolio for engineering assessment has been described by Williams. ${ }^{2}$ In recent years, a number of authors have identified various uses ${ }^{3}$ of the portfolio for the purposes of engineering education; this paper focuses on our experience of portfolio use for multi-year projects, in a progressive development lasting over several semesters, toward completion in a student's senior year.

The reflective component of the portfolio shows how well students have integrated liberal arts disciplines in their personal formation as an engineer, especially where addressing professional skills such as teamwork, communication, ethical judgment, and identifying societal context. Well-defined portfolio-documented aspects of project work also provide evidence suitable for educational assessment. The set of portfolio requirements presented here, which overall serves as a grand rubric in itself, facilitates individual student grading on diverse project applications over several semesters. A more specific rubric developed for each portfolio category addresses one aspect of the project work, and details expectations made as uniform as possible over the range of applications. The same portfolio material and rubrics serve as a measure for correlated items of the ABET assessment plan. This paper provides examples of multi-year multidisciplinary service learning projects at our institution, and describes the portfolio approach as it has been developed for the purposes of these multi-year projects, including sample rubrics.

\section{Introduction}

Increased emphasis on service learning ${ }^{1}$ in undergraduate engineering education has given rise to the need for an appropriate method to assess ongoing project work. The traditional senior project capstone course, based on a once-and-done concept, could rely 
on a checklist of engineering design-related activities in the rubric for a final project report, assuming students cycle through all phases of the design process in one academic year. However, practical service learning projects, in response to a community need, often require work extending over several years, in various phases of the design process. ${ }^{3}$ Thus, the engineering curriculum should accommodate the reality of such extended multi-year project work. Spreading credited time allotted for the capstone project over four or more successive semesters rather than merely two, has distinct benefits: it increases continuity of project work to sustain longevity of the service a client receives; it allows students more flexibility to work within the natural project phase; and it makes the vertical integration of student teams possible, offering increased opportunities for project management and leadership experience for students at the senior level. While such curriculum modification has clear benefits, the challenge of assessing ongoing project work in various phases remains formidable. This paper describes our experience of using portfolios to foster the educational development of undergraduate engineering students, while facilitating assessment of their multi-year project work, and illustrates how we adapt the portfolio development process to support our engineering project curriculum.

\section{Literature Review and the Unique Contribution of this Work}

While the value of a professional portfolio in other fields has been realized for some time, in engineering education, the benefits of a portfolio have only been recently recognized. It is known that the process of creating a portfolio encourages students to select, reflect on, and showcase best practice examples of their own work; as a complete product, the portfolio serves to display project experience with potential employers and colleagues, while they initiate their professional career. ${ }^{2}$ As such, the process of portfolio creation fosters effective educational practices of reflective judgment as advocated by King and Kitchener ${ }^{4}$ and self-authorship recommended by Baxter Magolda. ${ }^{5}$ The possibility of teaching and assessing ABET professional skills, and the advantage of doing so in the context of a global service learning program has been addressed by Shuman, BesterfieldSacre \& McGourty. ${ }^{6}$ Recent publications have reported on studies of portfolios used by undergraduate engineering students with regard to making personal sense of and developing a professional identity for engineering as a career (Eliot $\&$ Turns $^{7}$ ), what concepts students reveal about engineering as indicated by their written reflective entries (Dunsmore, Turns \& Yellin ${ }^{8}$ ), and the development of self-awareness related to life-long learning (Sattler, Kilgore $\&$ Turns $^{9}$ ). Eris has proposed the portfolio as a way of externalizing the learning process of an engineering student, with the potential to promote divergent inquiry, facilitating design. ${ }^{10}$ Recent presentations at the ASEE Annual Conference have addressed the initial development and implementation of an ePortfolio curriculum for engineering graduate students, ${ }^{11}$ developing self-authorship by creating "preparedness portfolios," portfolios to help students to take more responsibility for their personal and professional development, ${ }^{14}$ and using portfolios to help students narrate their design process. ${ }^{15}$ This paper provides unique practical knowledge gained from the experience of using portfolios to support a multi-year undergraduate project curriculum, by progressive completion over several semesters, aided by rubrics developed for each portfolio category that address practices inherent to an array of differing engineering concentrations. 
Background on Use of the Portfolio Approach and Multi-year Project Curriculum

The engineering department at this institution has been using portfolios to assess project work since 2007, when the multi-year engineering project curriculum was first implemented. This Integrated Projects Curriculum "builds on service-learning pedagogy... it embodies the three modes [...] required for service-learning: content, engagement, and reflection." "The IPC intersects with, and is further resourced by the Collaboratory for Strategic Partnerships and Applied Research, where engineering students interact with students in other disciplines. ${ }^{17}$ Messiah College is currently ABET accredited to offer the Bachelor of Science Degree in Engineering, with Biomedical, Civil, Computer, Electrical, Environmental or Mechanical concentrations. The IPC track begins with a Group Orientation (GO) course required by all engineering students, normally taken in the second semester of their sophomore year; the Engineering Project I-IV sequence follows GO, over the next four semesters through their senior year.

At the beginning of the GO course, students engage in a "Job Fair" activity to place them in one of seven application groups by a competitive Job Search ${ }^{18}$ process. Preparation for the Job Fair includes student leaders in consultation with faculty supervisors identifying a specific number of job openings on each ongoing project, and defining and posting a Job Description (JD) to go along with each position. The department allocates the number of openings allowed for each group so that the overall total number of positions matches the number of incoming GO students. Meanwhile, GO students prepare for the Job Fair by writing and posting a personal resume. After having read the current JDs, the Job Fair commences as all GO students witness a brief presentation by each group and/or project team, and then individually take a simulated "plant trip" by visiting and interviewing with a project team of interest at a designated location. Following the Job Fair, GO students "apply" for a job of interest by sending a cover letter to the group, and waiting for a job offer. Job offers are made by student leaders of each group and/or project, and if accepted by a student, the position is filled. The whole process is mediated online with an LMS, in our case using Sakai, as configured by the IPC managers for this purpose.

Once placed in an application group, students receive both common and group-specific background on basics that prepare them for project work over the next four semesters. Six engineering application groups currently identified at the author's institution include: BioMed, Communications, Disability Resources, Energy, Transportation and Water. These groups correspond to, and were each established by engineering faculty preference, considering their expertise and past experience with project work. IPC faculty receive 0.5 load credit per semester for each IPC course, with extra load credit for large student groups. Each IPC course is team taught with a section for each group, as above. Faculty with load credit advise, mentor and grade assignments. IPC managers who receive additional load credit, take responsibility for some common sessions, and overall coordination of course logistics. Our IPC students begin constructing and assembling the portfolio during Engineering Project I, and complete it at the end of Engineering Project IV (typically last semester of the senior year). Thus, portfolio assessment criteria must span not only the extent of multi-year engineering project work in various phases, but also the specialized fields of engineering practiced in all of the application groups. 
Purposes for Portfolio Assessment of Engineering Project Work

Over the 5+ years that the portfolio has been used, engineering department faculty have refined the approach to facilitate its use for both student and faculty purposes ${ }^{20}$ so as to address a full range of typical engineering design project activities. For students, having to assemble the portfolio motivates them to create, select and document best-practice examples of their engineering work, reflect on the significance of each artifact to the project, and evaluate its impact on their own formation as an engineer. As previously stated, the portfolio becomes a professional showcase they can share with potential employers as they initiate their career. ${ }^{2}$ Reflective self-evaluation of required commentary in the portfolio broadens students' educational perspective on their work, especially when addressing the softer or professional skills, ${ }^{6}$ and any aspect that includes humanitarian considerations and personal growth, not often directly addressed in traditional engineering courses. The categories of our portfolio, as discussed below, where the professional skills come into play most significantly include Communication, Research (including contemporary issues), Dissemination (oral \& written communication skills), Stakeholder Interaction, Problem Definition and Leadership \& Management. Thus, the wealth of a liberal arts education becomes a valuable resource for students when completing the reflective piece, and categories involving professional skills. For faculty, the portfolio facilitates educational assessment: assigning a component of the grade for each student in the individual engineering project course, and collecting aggregated student data suitable for assessing program outcomes to satisfy ABET.

\section{Methods}

This section of the paper describes methods used to adapt the portfolio approach for the purposes outlined above, and to the structure of the IPC track. It begins with a subsection identifying Designated Categories of Engineering Activity for Portfolio Entries specifying which of these are required or optional, and a rationale for such flexibility based on the nature of our ongoing IPC projects. The next subsection describes Specifications for Portfolio Presentation, and why we have students do it this way. The Weighting the Portfolio subsection identifies how much value the portfolio assignment receives, compared to other components of the project course grade. The following subsection, Addressing Differences Between Students' Academic Level explains how the increased credit and expectations of senior students is taken into account. The Establishing a Policy subsection describes our rules for progressive completion of the portfolio, over the course of several semesters. The Employing a Learning Management System explains how we facilitate grading with electronic rubrics. Finally, this section concludes with the Benefits and Challenges of creating rubrics we use to communicate detailed expectations of each portfolio category, and complete the semester grading.

\section{Designated Categories of Engineering Activity for Portfolio Entries}

In its present form, instructions for assembling the portfolio identify ten categories of engineering activity ${ }^{20}$ (see Table 1 ) that roughly parallel several corresponding ABET criteria. Students normally have four full semesters to demonstrate significant 
experiences by including documented entries in most (at least 7/10), but not necessarily all of these categories. From experience with the portfolio for assessment over that past several years, faculty have realized the need to maintain some flexibility with this requirement, rather than requiring all students to show examples in all categories, due to variations in the nature of ongoing projects (see Table 2), and the particular design phase being addressed when students have been contributing. Design phases include Project Identification, Specification Development, Conceptual Design, Detailed Design, Delivery and Maintenance, etc. ${ }^{19}$ Since some of the portfolio category activities may be more central than others for engineering education, by consensus, the department has decided to require entries for the first three categories listed in Table 1, and two out of the next three. It may be surprising to some that we do not require Analysis for every portfolio, but the particular design phase and project focus may dictate other priorities; students' ability to analyze is already measured well in traditional engineering course work. Entries for at least two other categories for a total of seven sections of the portfolio must be included by the end of Engineering Project IV. In this way, the department has prioritized the first five or six of the ten total engineering categories of activities as more essential, for the purpose of portfolio assembly and educational assessment.

\begin{tabular}{|l|l|l|}
\hline $\begin{array}{l}\text { Portfolio Category } \\
\text { of Activity }\end{array}$ & $\begin{array}{l}\text { Brief Description (more detailed criteria available } \\
\text { in the rubric associated with each category) }\end{array}$ & Required? \\
\hline Communication & $\begin{array}{l}\text { Enables others on the team to succeed: timely, } \\
\text { professional, both face-to-face \& online modes }\end{array}$ & Yes \\
\hline Research & $\begin{array}{l}\text { Succeeds in discovering state of the art: best past } \\
\text { solutions, best products, theory \&/or techniques }\end{array}$ & Yes \\
\hline Dissemination & $\begin{array}{l}\text { Enables others to replicate or extend: written } \\
\text { reports \& publications, oral presentation \& slides }\end{array}$ & Yes \\
\hline Analysis & $\begin{array}{l}\text { Applies math \& science principles to predict } \\
\text { behavior: for design \&/or for testing }\end{array}$ & $\begin{array}{l}\text { No } \\
\text { (2/3 option) }\end{array}$ \\
\hline Prototyping & $\begin{array}{l}\text { Verifies performance \& informs next design cycle: } \\
\text { drawings \& solid models, components fabricated to } \\
\text { tolerance, software coding, assembly, client fdbk }\end{array}$ & $\begin{array}{l}\text { No } \\
\text { (2/3 option) }\end{array}$ \\
\hline Testing & $\begin{array}{l}\text { To verify performance or understand failures: } \\
\text { design \& conduct experiments, interpret data }\end{array}$ & $\begin{array}{l}\text { No } \\
\text { (2/3 option) }\end{array}$ \\
\hline $\begin{array}{l}\text { Stakeholder } \\
\text { Interaction }\end{array}$ & $\begin{array}{l}\text { To assure the team solves the right problem: needs } \\
\text { eval'n, results assessed, improves due to client fdbk }\end{array}$ & $\begin{array}{l}\text { No } \\
\text { (2/4 option) }\end{array}$ \\
\hline $\begin{array}{l}\text { Problem } \\
\text { Definition }\end{array}$ & $\begin{array}{l}\text { Knows what to do w/ human resources in a weekly } \\
\text { cycle: ends, means and success well-defined }\end{array}$ & $\begin{array}{l}\text { No } \\
\text { (2/4 option) }\end{array}$ \\
\hline $\begin{array}{l}\text { Management \& } \\
\text { Leadership }\end{array}$ & $\begin{array}{l}\text { Accomplished objectives on time: defines team } \\
\text { values, plans \& runs mtgs, SMART goals, etc. }\end{array}$ & $\begin{array}{l}\text { No } \\
\text { (2/4 option) }\end{array}$ \\
\hline $\begin{array}{l}\text { Economic } \\
\text { Analysis }\end{array}$ & $\begin{array}{l}\text { Enables project to succeed and sustain results: } \\
\text { budgeting, justification, sustainability }\end{array}$ & $\begin{array}{l}\text { No } \\
\text { (2/4 option) }\end{array}$ \\
\hline
\end{tabular}

Table 1. Portfolio categories for student entries with description and requirement status

As mentioned above, Table 2 shows a range of ongoing, multi-year service-learning projects being addressed by our teams, illustrating their wide-ranging applications and 
global scope. The project teams consisting of 2-8 students each are advised by at least one faculty member, and often receive assistance from other outside consultants or stakeholders. Each IPC faculty member is responsible for one of the groups, which may host multiple projects, as indicated below.

\begin{tabular}{|c|c|}
\hline $\begin{array}{l}\text { Project } \\
\text { (Host } \\
\text { Group) }\end{array}$ & Brief Description (more detailed description available at project page) \\
\hline $\begin{array}{l}\text { Moxy } \\
\text { (Biomed) }\end{array}$ & $\begin{array}{l}\text { Design \& construct oxygen concentrators for Macha Hospital in Zambia, } \\
\text { where many patients suffer from Tuberculosis related to HIV/AIDS, } \\
\text { to provide patients with supplemental oxygen for optimum treatment }\end{array}$ \\
\hline $\begin{array}{l}\text { FTMS } \\
\text { (Comm. } \\
\text { Tech.) }\end{array}$ & $\begin{array}{l}\text { Flight Tracking \& Messaging Systems: upgrading JAARS Automatic } \\
\text { Flight Following System (AFFS) with a current microprocessor; radio- } \\
\text { link automatically tracks small planes flying in remote locations }\end{array}$ \\
\hline $\begin{array}{l}\text { WERC } \\
\text { (Comm. } \\
\text { Tech.) }\end{array}$ & $\begin{array}{l}\text { Wireless Enabled Remote Co-presence: developing system to wirelessly } \\
\text { deliver job \& life coaching services from a remote location to persons } \\
\text { with conditions from high-functioning autism to traumatic brain injury }\end{array}$ \\
\hline $\begin{array}{l}\text { MMT } \\
\text { (Comm. } \\
\text { Tech.) }\end{array}$ & $\begin{array}{l}\text { Develop a small hand-held device, like a Gameboy, designed to aid the } \\
\text { teachers in Burkina Faso (BF) by providing students with supplemental } \\
\text { activities and educational games for independent learning }\end{array}$ \\
\hline $\begin{array}{l}\text { Mobility } \\
\text { (Dis. Res.) }\end{array}$ & $\begin{array}{l}\text { Develop personal transportation technologies for those with limited } \\
\text { mobility in BF, such as hand-powered and electric tricycles }\end{array}$ \\
\hline $\begin{array}{l}\text { Biodiesel } \\
\text { (Energy) }\end{array}$ & $\begin{array}{l}\text { Develop processes to produce biodiesel as an alternative fuel at home \& } \\
\text { abroad, to educate \& promote environmental \& economic sustainability }\end{array}$ \\
\hline $\begin{array}{l}\text { KWHr meter } \\
\text { (Energy) }\end{array}$ & $\begin{array}{l}\text { Develop a device to monitor \& manage the amount of electrical energy } \\
\text { used by a house or small building in } \mathrm{BF} \text {, based on a set energy quota }\end{array}$ \\
\hline $\begin{array}{l}\text { LSA } \\
\text { (Trans.) }\end{array}$ & $\begin{array}{l}\text { Develop necessary components (e.g., engine mount, suspension, exhaust } \\
\text { system, gas tank, radiator, electrical instruments, wings, etc.) for a low- } \\
\text { cost Light Sport Aircraft, suitable for use in remote locations }\end{array}$ \\
\hline $\begin{array}{l}\text { SCV } \\
\text { (Trans.) }\end{array}$ & $\begin{array}{l}\text { Develop a Solar Commuter Vehicle (zero emissions motorcycle) that is } \\
\text { economical \& practical for commuting purposes; includes a brushless } \\
\text { electric in-hub motor, a lithium-ion battery pack \& solar charging station }\end{array}$ \\
\hline $\begin{array}{l}\text { India MKII } \\
\text { (Water) }\end{array}$ & $\begin{array}{l}\text { Improving the India Mark II pump platform by remedying failures, } \\
\text { increasing its longevity while maintaining economic feasibility }\end{array}$ \\
\hline $\begin{array}{l}\text { GWA } \\
\text { (Water) }\end{array}$ & $\begin{array}{l}\text { Garden Water Access: Provide an economically viable irrigation solution } \\
\text { that enables inhabitants of arid, rural regions to increase production of } \\
\text { self-sustaining and income generating crops }\end{array}$ \\
\hline $\begin{array}{l}\text { HFM } \\
\text { (Water) }\end{array}$ & $\begin{array}{l}\text { Develop water purification systems using Hollow Fiber Membrane filter } \\
\text { technology, to meet the needs of people in Nicaragua in an } \\
\text { economically, environmentally, and culturally sustainable manner }\end{array}$ \\
\hline $\begin{array}{l}\text { VWOS } \\
\text { (Water) }\end{array}$ & $\begin{array}{l}\text { Village Water Ozonation System: developing \& implementing a } \\
\text { filtration \& ozone injection system to disinfect water in Honduras }\end{array}$ \\
\hline
\end{tabular}

Table 2. Examples of the variety of ongoing multi-year service learning projects hosted within the indicated engineering application group at Messiah College 
Specifications for Portfolio Presentation: Format and Frequency of Submission

Other practical details associated with the portfolio assignment include specifications for its form of presentation, format of contents, and submission. Several authors have advocated an electronic portfolio approach. ${ }^{11,14,22,23}$ Our students prepare their portfolio entries first in electronic form, but for presentation, we require a paper copy of the portfolio in a 3-ring loose-leaf binder with section dividers, since it is easy to carry by hand to a prospective employer for perusal. In the future, we may move to an electronic form of portfolio presentation, but at present, we prefer to keep learning web site development as an optional skill for students, and encourage the use of video and sound files only if they make a more effective oral presentation (as evaluated elsewhere), rather than in the portfolio. Thus, we specify that written portfolio materials must be wordprocessed on standard 8-1/2" x 11 " paper. Photos, diagrams, graphs and other artifacts must include labels. Within the binder, the complete portfolio includes the following elements in order: a title page, a table of contents, an introductory statement, one or more entries for each required portfolio category (as indicated in Table 1) including artifact documentation with reflective commentary on each activity, and a closing summary. Future research on these format options may help identify which is the best to achieve student learning.

During each semester of Engineering Project, a student begins by planning semester progress on the portfolio, by selecting one or more recognized engineering activities from the list, as necessary, in consultation with the faculty advisor for that application group. Considerations for portfolio planning include nature of the project, current status of its design phase, and previous progress on the portfolio. At the end of each semester, the engineering project student must submit the portfolio for grading. Although a portfolio submitted before the end of a student's senior year must be considered a "work in progress," comparable to the first draft of a paper submitted before the final one, students understand that required elements of the portfolio, as arranged with the faculty advisor during the planning phase, will be graded. This process insures adequate progress on the Portfolio at each stage of the Engineering Project I-IV sequence, and provides one valuable form of assessment on the quality of the student's project work over that semester, generating a significant component of that student's semester grade.

Weighting the Portfolio as a Component of the Project Course Grade

While portfolio assessment does serve as an important measure of a student's project work, other significant components of the student's activity will likely be included in the overall course grade to be complete, as laid out in the syllabus for a project course. At our institution, for the Engineering Project sequence, besides the Portfolio component worth $20 \%$, we include Progress against the semester plan (20\%), Reporting and Documentation (40\%), On Time completion of assigned tasks (15\%), Logbook (5\%) and an Adjustment Factor (+/-5\%). The Progress against the semester plan component is based on measurable goals set by the project team with approval by the faculty advisor near the beginning, and evaluated by the team at the end of the semester, as reported in a Project Management Document (PMD). The faculty advisor assigns the same grade to all 
members of the project team, based on progress against each goal, with a maximum possible score of 20/20. The Reporting and Documentation component worth a total of 40\% breaks down as follows: $25 \%$ is allotted to a written report addressing issues identified in the Project Outcomes Document (POD) specific to the design phase of a particular project, and the other $15 \%$ is allotted to a presentation each semester to a particular audience. On Time completion of tasks is measured by student leaders on the basis of weekly tasks assigned and completed by team members, using TeamworkPM (http://www.teamworkpm.net/) as a tool. Though TeamworkPM is available for free individual use, we select the Corporate option at a monthly premium to accommodate a sufficient number of projects and adequate online storage space. Logbook ${ }^{21}$ instructions specify for students to clearly identify personal contact information in case of loss, divide the composition book into logical sections, and bring to all project related meetings and class sessions. Besides these basic expectations for its use, the logbook is graded on content, organization and neatness. The Adjustment Factor allows a student's grade to be increased or decreased based on self, peer and faculty evaluation of that student's overall contribution and growth during the semester. Thus, we believe the portfolio approach works best with other forms of assessment, as indicated here, to generate a more complete picture of a student's progress on credited engineering project work. Besides considering how much weight the portfolio assessment should receive, the greater expectation for progress by senior students, including their leadership and management responsibilities, needs to be taken into account in the number of credits they earn, and in the structuring of portfolio requirements, as explained in the next two sections.

\section{Addressing Differences Between Students' Academic Level in Project Work}

A multi-year engineering project curriculum and its portfolio assessment approach must address the reality that students at lower academic levels are typically less prepared than seniors to make significant project contributions, and often unready to assume management and leadership responsibilities. While project management and leadership responsibilities assumed by seniors help bridge this gap, our department also designates twice as much credit for senior level project courses (Engineering Project III \& IV at 2 credits each) than the junior level project courses (Engineering Project I \& II at 1 credit each). During one previous semester, we also attempted to boost the grades of junior students with an adjustment factor in rubric calculations, but found that such an approach led to unjustifiable grade inflation, so we have abandoned that approach in favor of common grading rubrics, as applied to students at either the junior or senior level. The difference in course credit affects both the amount of time we expect students to spend on IPC project work, and progress they should make toward completion of their portfolio.

Establishing a Policy on the Progress of Portfolio Completion

Reasonable expectation of progress must be set on the collection and presentation of portfolio entries by students. For practicality, we tie the policy of progress on portfolio entry categories to the number of credits in each project course. Thus, each semester, a project student must include an entry (i.e., artifact(s) and reflective commentary) for at least one activity per project course credit. Each new entry must be in a category not 
previously addressed by the portfolio submitted in previous semesters. The student is also expected to update the title page, table of contents, and introductory statement as necessary, but only an acceptable draft is expected until the final semester. If desired, students may exceed the minimum entry requirement number by submitting one or more entries in other new categories. Students are also allowed to substitute more up-to-date best-practice examples in existing sections of their portfolio, to replace the older and/or inferior artifact, and may request a re-grade on that section averaged in with the other new ones for that semester. Thus, for any re-graded portfolio section, the new grade does not substitute for the grade received on that section in a previous semester, keeping regraded categories to a minimum. With the portfolio progress policy, and the total number of 6 credits offered to students for the Engineering Project I-IV sequence, a student keeping to the minimum number of section entries required each semester will end up with only 6 categories. Thus, to reach the minimum number of 7 total section entries required for the completed portfolio, a student must include at least one more entry than required, during a semester of choice. This progress policy allows students to develop portfolios at a slower pace during their junior year, a reasonable expectation while they are "getting up to speed" on project work during their first year of experience.

Employing a Learning Management System to Facilitate Grading with Rubrics

As a practical issue of organization and implementation, portfolio assessment will ideally be tailored to the learning management system (LMS) that an educational institution supports. Our IPC managers have chosen to use Sakai (http://www.sakaiproject.org/), since it is an open source LMS currently available and supported at our institution. Features of Sakai allow project students to be organized by application group, so that the faculty advisor of an application group has access in the Grade Book to students only within that group. For convenience, iRubric (http://www.rcampus.com/indexrubric.cfm) is a tool that links directly to the Sakai Grade Book, to complete assessment in electronic form. Thus, once the rubric grid and corresponding weights has been established for a portfolio category in iRubric, students can view these expectations from the beginning of the semester to guide them in developing their portfolio entries. Furthermore, at the end of the semester, student entries within that category can easily be graded as a matter of clicking the appropriate selections on the grid. Since graded categories of the portfolio apply only as a component of the project course grade for one semester, it is not necessary to keep a record of those grades in Sakai for future reference, although Sakai does have the capability to do so. In short, we find Sakai and iRubric convenient time saving tools, though other similar tools may work as well if adequately developed, but grading each portfolio item is not as much about the tool as it is the quality of the rubric, which must be constructed carefully to properly reflect expectations for that category.

\section{Benefits and Challenges to Creating a Quality Rubric}

A properly constructed rubric for each portfolio category communicates to students clearly the expected form and content for each entry, increasing quality and uniformity of their submissions. Furthermore, a well-formed rubric facilitates accurate, uniform and efficient grading by faculty. In our department, faculty have invested considerable time 
over the past year refining and revising portfolio rubrics for this purpose. While the work of refining each rubric can be tedious, increasing the accuracy and uniformity of these expectations makes it worthwhile. Challenges to the process of forming rubrics include: a) reaching a collective faculty consensus on how to define each aspect of the engineering process, as identified by each particular portfolio category, and b) describing the expectation in a way that addresses multiple engineering concentrations and differing engineering practices. For example, while choosing a material property, constructing an electrical circuit board, or coding a microprocessor may each qualify as an engineering endeavor, each is governed by somewhat unique considerations. Though our process by committee of department faculty was relatively slow, we believe the product of rubrics formed were more uniform and broadly applicable to diverse project applications as a result of including faculty with varied expertise. Thus, delegating the task of rubric development to smaller subcommittees might save time, but may not result in criteria with sufficient breadth.

\section{Results}

Portfolio assessment serves as only one way to gather data useful for evaluating how well an ABET outcome has been achieved by an engineering program. The convenience of having collected portfolio data for student assessment provides a time saving advantage. In our case, we have been evaluating two outcomes per semester, using aggregated data derived from the portfolio category rubric most closely associated with the ABET outcome. For example, the overall averages for Problem Definition and Testing, both evaluated Fall 2012, along with rubric descriptions are shown in Tables $3 \& 4$ below.

Department policy is to establish an acceptable standard on the scale for each ABET outcome, and determine whether the portfolio average falls above or below that standard. If above, that outcome has passed. If below, changes are made to the inputs of that outcome, and it is evaluated again the following semester.

Results for Problem Definition (Table 3) show that the seven students who chose this category during the Fall 2012 semester achieved at a level of 4.31/5.00, based on the overall weighted average, which exceeds our threshold. However, two students $(2 / 7=29 \%)$ failed to reach the threshold on Setting/Context and Content of the Reflection. On the Performance Specifications criterion, the average score of 3.86 including four students $(4 / 7=57 \%)$ that failed to reach the threshold. Thus, the latter result suggests that we re-evaluate how well we are preparing students to identify and quantify all constraints necessary to complete a successful solution to the problem being addressed by a project.

Results for Testing (Table 4) show that the thirteen students who chose this category during the Fall 2012 semester achieved at a level of 4.52/5.00, based on the overall weighted average, which also exceeds our threshold. While only one or two students fell below the threshold on any given criterion in this result during Fall 2012, it should be noted that during the previous semester (Spring 2012), the result for Testing had been 3.44/5.00 overall, triggering a re-evaluation of the Testing category during the Fall 2012 
semester. The improvement may be attributed to better preparation by faculty advisors on the issues and expectations associated with Testing, as outlined in the Testing rubric.

In these examples, skills of a liberal arts education come to bear at least in writing the reflection part of both the Problem Definition and Testing categories of the portfolio, as well as the Statement of Need criterion of the Problem Definition. Besides the skills of writing effectively, and reflecting productively on personal growth, in Statement of Need, students must diagnose the human requirement perceptively without foreclosing on possible solution strategies. In Exploration of Solution Strategies, students must compare the strengths and weaknesses of different approaches, before settling on a recommended one. Such evaluation requires critical thinking and ability to review relevant literature.

\begin{tabular}{|c|c|c|c|c|c|}
\hline $\begin{array}{l}\text { Problem } \\
\text { Definition } \\
\text { Criterion }\end{array}$ & $\begin{array}{l}\text { Exemplary } \\
\text { /Excellent } \\
\text { (5 pts) }\end{array}$ & $\begin{array}{l}\text { Accmplished } \\
\text { /Good } \\
\text { (4 pts) }\end{array}$ & $\begin{array}{l}\text { Developing } \\
\text { /Fair } \\
\text { (3 pts) }\end{array}$ & $\begin{array}{l}\text { Deficient } \\
\text { /Poor } \\
(2 \mathrm{pts})\end{array}$ & $\begin{array}{l}\text { Fall } \\
2012 \\
\text { Avg }\end{array}$ \\
\hline $\begin{array}{l}\text { Reflection } \\
\text { Setting/ } \\
\text { Context } \\
\text { (1) }\end{array}$ & $\begin{array}{l}\text { References project } \\
\text { assignment, relates to } \\
\text { proj. goals, complet'n } \\
\text { /submiss'n timeliness, } \\
\& \text { co-workers }\end{array}$ & $\begin{array}{l}\text { References proj. } \\
\text { assignment, } \\
\text { completion date, } \\
\& \text { co-workers } \\
\text { involved }\end{array}$ & $\begin{array}{l}\text { References only } \\
\text { the project } \\
\text { assignment that } \\
\text { lead to the } \\
\text { portfolio entry }\end{array}$ & $\begin{array}{l}\text { Fails to relate } \\
\text { portfolio entry } \\
\text { to overall } \\
\text { project }\end{array}$ & 4.29 \\
\hline $\begin{array}{l}\text { Reflection } \\
\text { Appearnce } \\
\text { (1) }\end{array}$ & $\begin{array}{l}\text { Properly formatted } \\
\text { word-processed } \\
\text { document on resume } \\
\text { quality paper }\end{array}$ & $\begin{array}{l}\text { Properly } \\
\text { formatted word- } \\
\text { processed } \\
\text { document }\end{array}$ & $\begin{array}{l}\text { Neatly } \\
\text { handwritten or } \\
\text { unformatted } \\
\text { type }\end{array}$ & $\begin{array}{l}\text { Illegible or } \\
\text { sloppy }\end{array}$ & 5.00 \\
\hline $\begin{array}{l}\text { Reflection } \\
\text { Writing } \\
\text { Mech. (1) }\end{array}$ & $\begin{array}{l}\text { No grammatical or } \\
\text { spelling errors }\end{array}$ & $\begin{array}{l}\text { Few grammatical } \\
\text { or spelling errors }\end{array}$ & $\begin{array}{l}\text { Errors exist \& } \\
\text { detract some }\end{array}$ & $\begin{array}{l}\text { Errors detract } \\
\text { much }\end{array}$ & 5.00 \\
\hline $\begin{array}{l}\text { Reflection } \\
\text { Content } \\
(2)\end{array}$ & $\begin{array}{l}\text { Summarizes } \\
\text { contribution, shows } \\
\text { mastery of category \& } \\
\text { personal growth }\end{array}$ & $\begin{array}{l}\text { Summarizes } \\
\text { contrib., \& offers } \\
\text { evidence for } \\
\text { mastery of catgry }\end{array}$ & $\begin{array}{l}\text { Summarizes } \\
\text { the student's } \\
\text { contribution } \\
\text { only } \\
\end{array}$ & $\begin{array}{l}\text { Rambling } \\
\text { gibberish }\end{array}$ & 4.14 \\
\hline $\begin{array}{l}\text { Entry } \\
\text { Statement } \\
\text { of Need(2) }\end{array}$ & $\begin{array}{l}\text { Concise \& compelling } \\
\text { reasons that need will } \\
\text { be met; no particular } \\
\text { sol'n strategy assumed }\end{array}$ & $\begin{array}{l}\text { Understandable; } \\
\text { open to multiple } \\
\text { sol'n strategies, } \\
\text { writing rough }\end{array}$ & $\begin{array}{l}\text { Understandable } \\
\text { but points to } \\
\text { specific sol'n } \\
\text { strategies }\end{array}$ & $\begin{array}{l}\text { Present but } \\
\text { unclear }\end{array}$ & 4.43 \\
\hline $\begin{array}{l}\text { Entry } \\
\text { Explortion } \\
\text { of Sol'n } \\
\text { Stratg's(2) }\end{array}$ & $\begin{array}{l}\text { Alternative sol'ns \& } \\
\text { their relative merits } \\
\text { explored; case for } \\
\text { recommended sol'n } \\
\text { well reasoned \& } \\
\text { supported by the lit. }\end{array}$ & $\begin{array}{l}\text { Other sol'ns \& } \\
\text { their relative } \\
\text { merits explored, } \\
\text { but case for } \\
\text { propos'd sol'n } \\
\text { not well supprtd }\end{array}$ & $\begin{array}{l}\text { Other sol'ns \& } \\
\text { their relative } \\
\text { merits not } \\
\text { adequately } \\
\text { explored OR no } \\
\text { sol'n proposed }\end{array}$ & $\begin{array}{l}\text { Other sol'ns \& } \\
\text { relative merits } \\
\text { not adequately } \\
\text { explored AND } \\
\text { no sol'n } \\
\text { proposed }\end{array}$ & 4.14 \\
\hline $\begin{array}{l}\text { Entry } \\
\text { Perfrmnce } \\
\text { Spec's (2) }\end{array}$ & $\begin{array}{l}\text { All constraints needed } \\
\text { for a successful sol'n } \\
\text { have been identified \& } \\
\text { quantified }\end{array}$ & $\begin{array}{l}\text { Most constraints } \\
\text { for successful } \\
\text { sol'n have been } \\
\text { id'd \& quantif'd }\end{array}$ & $\begin{array}{l}\text { Most constr'nts } \\
\text { have been id'd } \\
\text { but are not fully } \\
\text { quantified }\end{array}$ & $\begin{array}{l}\text { Significant } \\
\text { constraints for } \\
\text { success have } \\
\text { not been id'd }\end{array}$ & 3.86 \\
\hline \multicolumn{5}{|c|}{ Weighted Average of All Criteria } & 4.31 \\
\hline
\end{tabular}

Table 3. Detailed descriptions and average scores for the Problem Definition portfolio category rubric on each criterion, including overall weighted average, at the end of the Fall 2012 semester for the $\mathrm{N}=7$ students who chose this portfolio category that semester. 


\begin{tabular}{|c|c|c|c|c|c|}
\hline $\begin{array}{l}\text { Testing } \\
\text { Criteria } \\
\text { (weight) }\end{array}$ & $\begin{array}{l}\text { Exemplary } \\
\text { /Excellent } \\
(5 \text { pts }) \\
\end{array}$ & $\begin{array}{l}\text { Accomplished } \\
\text { /Good } \\
(4 \mathrm{pts}) \\
\end{array}$ & $\begin{array}{l}\text { Developing } \\
\text { /Fair } \\
(3 \mathrm{pts})\end{array}$ & $\begin{array}{l}\text { Deficient } \\
\text { /Poor } \\
(2 \text { pts }) \\
\end{array}$ & $\begin{array}{l}\text { Fall } \\
2012 \\
\text { Avg. }\end{array}$ \\
\hline $\begin{array}{l}\text { Reflection } \\
\text { Setting/ } \\
\text { Context } \\
\text { (1) }\end{array}$ & $\begin{array}{l}\text { References project } \\
\text { assignment, relates to } \\
\text { proj. goals, complet'n } \\
\text { /submiss'n timeliness, } \\
\& \text { co-workers }\end{array}$ & $\begin{array}{l}\text { References proj. } \\
\text { assignment, } \\
\text { completion date, } \\
\text { \& co-workers } \\
\text { involved }\end{array}$ & $\begin{array}{l}\text { References only } \\
\text { the project } \\
\text { assignment that } \\
\text { lead to the } \\
\text { portfolio entry }\end{array}$ & $\begin{array}{l}\text { Fails to relate } \\
\text { portfolio } \\
\text { entry to } \\
\text { overall } \\
\text { project }\end{array}$ & 4.62 \\
\hline $\begin{array}{l}\text { Reflection } \\
\text { Appear- } \\
\text { ance (1) }\end{array}$ & $\begin{array}{l}\text { Properly formatted } \\
\text { word-processed } \\
\text { document on resume } \\
\text { quality paper }\end{array}$ & $\begin{array}{l}\text { Properly } \\
\text { formatted word- } \\
\text { processed } \\
\text { document }\end{array}$ & $\begin{array}{l}\text { Neatly } \\
\text { handwritten or } \\
\text { unformatted type }\end{array}$ & $\begin{array}{l}\text { Illegible or } \\
\text { sloppy }\end{array}$ & 4.77 \\
\hline $\begin{array}{l}\text { Reflection } \\
\text { Writing } \\
\text { Mech(1) }\end{array}$ & $\begin{array}{l}\text { No grammatical or } \\
\text { spelling errors }\end{array}$ & $\begin{array}{l}\text { Few grammatical } \\
\text { or spelling errors }\end{array}$ & $\begin{array}{l}\text { Errors exist \& } \\
\text { detract some }\end{array}$ & $\begin{array}{l}\text { Errors detract } \\
\text { much }\end{array}$ & 4.92 \\
\hline $\begin{array}{l}\text { Reflection } \\
\text { Content } \\
\text { (2) } \\
\end{array}$ & $\begin{array}{l}\text { Summarizes } \\
\text { contribution, shows } \\
\text { mastery of category \& } \\
\text { personal growth } \\
\end{array}$ & \begin{tabular}{|l|} 
Summarizes \\
contrib., \& offers \\
evidence for \\
mastery of catgry \\
\end{tabular} & $\begin{array}{l}\text { Summarizes the } \\
\text { student's } \\
\text { contribution only }\end{array}$ & $\begin{array}{l}\text { Rambling } \\
\text { gibberish }\end{array}$ & 4.62 \\
\hline $\begin{array}{l}\text { Entry } \\
\text { Purpose } \\
\text { Stmnt(2) }\end{array}$ & Clear \& valid & $\begin{array}{l}\text { Valid reason, but } \\
\text { stated unclearly }\end{array}$ & $\begin{array}{l}\text { Clearly stated, but } \\
\text { incorrect }\end{array}$ & $\begin{array}{l}\text { Neither clear } \\
\text { nor correct }\end{array}$ & 4.62 \\
\hline $\begin{array}{l}\text { Entry } \\
\text { Ident. of } \\
\text { Var's (2) }\end{array}$ & $\begin{array}{l}\text { All var's identified \& } \\
\text { expected values } \\
\text { quantified if available }\end{array}$ & \begin{tabular}{|l|} 
Most variables \\
identif'd \& val's, \\
quantif'd if avail
\end{tabular} & $\begin{array}{l}\text { Test variables } \\
\text { omitted \&/or } \\
\text { values not quant'd }\end{array}$ & $\begin{array}{l}\text { Test var's \& } \\
\text { quant val's } \\
\text { omitted }\end{array}$ & 4.38 \\
\hline $\begin{array}{l}\text { Entry } \\
\text { Exp't } \\
\text { Dsgn(2) }\end{array}$ & $\begin{array}{l}\text { Has high chance of } \\
\text { producing reliable data } \\
\text { (proper techniques, } \\
\text { devices, \& variations) }\end{array}$ & $\begin{array}{l}\text { Has moderate } \\
\text { chance of prdcng } \\
\text { reliable data } \\
\text { (proper t, d \& v) }\end{array}$ & $\begin{array}{l}\text { T, d \& v's } \\
\text { addressed, but } \\
\text { exp't unlikely to } \\
\text { prdc reliable data }\end{array}$ & $\begin{array}{l}\text { Little or no } \\
\text { consideration } \\
\text { for expt's t, d, } \\
\text { or statistcl v's }\end{array}$ & 4.38 \\
\hline $\begin{array}{l}\text { Entry } \\
\text { Test } \\
\text { Doc. (2) }\end{array}$ & $\begin{array}{l}\text { Clear, reproducible } \\
\text { test procedure with } \\
\text { fully annoted drawings } \\
\text { or images of test setup }\end{array}$ & $\begin{array}{l}\text { Reproducible } \\
\text { test procedure } \\
\text { with minor } \\
\text { deficiencies } \\
\end{array}$ & $\begin{array}{l}\text { Test procdre gives } \\
\text { general setup, but } \\
\text { not enough info to } \\
\text { reproduce exp't }\end{array}$ & $\begin{array}{l}\text { Significant } \\
\text { components } \\
\text { of test doc are } \\
\text { missing }\end{array}$ & 4.17 \\
\hline $\begin{array}{l}\text { Entry } \\
\text { Data } \\
\text { Coll. (2) }\end{array}$ & $\begin{array}{l}\text { Exp't performed with } \\
\text { a high likelihood to } \\
\text { produce reliable data }\end{array}$ & $\begin{array}{l}\text { Exp't perfrmd w/ } \\
\text { moderate chance } \\
\text { of reliable data }\end{array}$ & $\begin{array}{l}\text { Haphazard expt'l } \\
\text { method leading to } \\
\text { unreliable data }\end{array}$ & $\begin{array}{l}\text { Exp't } \\
\text { performed } \\
\text { incorrectly }\end{array}$ & 4.54 \\
\hline $\begin{array}{l}\text { Entry } \\
\text { Pres. of } \\
\text { Data (2) }\end{array}$ & $\begin{array}{l}\text { Orderly \& complete } \\
\text { indepndntly verifiable }\end{array}$ & $\begin{array}{l}\text { Complete, but } \\
\text { not indep. } \\
\text { verifiable }\end{array}$ & Data incomplete & $\begin{array}{l}\text { Incomplete \& } \\
\text { disorganized }\end{array}$ & 4.50 \\
\hline $\begin{array}{l}\text { Anal. of } \\
\text { Reslts(2) }\end{array}$ & $\begin{array}{l}\text { Analysis complete \& } \\
\text { interpretation is } \\
\text { thorough \& accurate }\end{array}$ & \begin{tabular}{|l|} 
Analysis OK, but \\
interpretation not \\
complete or OK \\
\end{tabular} & $\begin{array}{l}\text { Analysis } \\
\text { incomplete or } \\
\text { interp. flawed }\end{array}$ & $\begin{array}{l}\text { Analysis } \\
\text { erroneous }\end{array}$ & 4.58 \\
\hline $\begin{array}{l}\text { Interp of } \\
\text { Reslts(2) }\end{array}$ & $\begin{array}{l}\text { Interprets \& applies } \\
\text { results in view of the } \\
\text { purpose of the test w/ } \\
\text { supported conclusion }\end{array}$ & $\begin{array}{l}\text { Draws a proper } \\
\text { conclusion from } \\
\text { results, but conc- } \\
\text { lusion unsupprtd } \\
\end{array}$ & $\begin{array}{l}\text { Uses results to } \\
\text { support improper } \\
\text { conclusion }\end{array}$ & $\begin{array}{l}\text { Improper } \\
\text { conclusions } \\
\text { drawn w/o } \\
\text { support } \\
\end{array}$ & 4.55 \\
\hline \multicolumn{5}{|c|}{ Weighted Average of All Criteria } & 4.52 \\
\hline
\end{tabular}

Table 4. Detailed descriptions and average scores for the Testing portfolio category rubric on each criterion, including overall weighted average, at the end of the Fall 2012 semester for the $\mathrm{N}=13$ students who chose this portfolio category that semester. 


\section{Summary \& Conclusions}

This paper has presented a portfolio approach for assessing multi-year engineering projects, illustrated by its application for service learning projects being conducted by undergraduates students and faculty in an engineering program at Messiah College. The Background section in the Introduction has described the origins and structure of the project curriculum at our institution, including the specific application groups we have identified. After revision over a few years of experience, we have developed clearer rubrics for each category, and criteria that are relevant over a broader range of project applications. Our current portfolio progress completion policy now has more flexibility (than a one size and order fits all) to address design processes and applications whose rates of development and phase differ naturally from one to project to the next. Results of the Problem Definition and Testing outcomes show how aggregated data from portfolio assessment has helped us evaluate ABET outcomes and inform continuous improvement. Sample rubric criteria reveal that writing reflective commentaries on project need, solution strategies and personal growth requires skills of a liberally educated student to produce a quality product. Human factors must be assessed, solution strategies evaluated, and critical thinking must be applied to plan a future direction effectively, in the light of past results. During such reflection, students learn to go beyond merely taking project results at "face value" to find meaning at a deeper level.

For those who wish to implement a similar portfolio approach for multi-year engineering projects, several key aspects of the approach have been identified. While faculty preferences, expertise and resources will vary, resulting in groups of different specialization and number, from the outset, the purposes for portfolio assessment should be clearly stated and understood, among both faculty and students. Portfolio categories of engineering activity should be well-defined, and for practicality, may well parallel a corresponding list of ABET assessment outcomes. Practical details of portfolio construction and submission should be set, and communicated as instructions to students, including acceptable specifications for its form of presentation, format of contents, and due dates. While portfolio assessment serves as an important measure a student's project work, other significant components of the student's semester grade will likely be included for completeness, as laid out in the syllabus for a project course. Decisions on how much weight the portfolio assessment receives, and which other grade components are included will vary depending on the context and circumstances at each institution. Differences between the preparedness of students at lower academic levels, as compared to seniors, should be taken into account, if not already addressed in the structure of the project curriculum. Seniors should be expected to make more progress than other students toward overall completion of the portfolio. Taking full advantage of the LMS supported by the institution may help facilitate practical details of the grading process, and for convenience, link a specific rubric to each portfolio category. A quality rubric for each portfolio category establishes clear guidelines and expectations to students for grading, in a way that fairly and uniformly addresses the variety of techniques and practices applied across the engineering disciplines at the institution. 
Future research on this work will help establish the best portfolio presentation format, consistent rubric application and the impact of another LMS alternative.

\section{Acknowledgements}

Thanks to those who contributed to this work including IPC managers Tim Van Dyke and Barbara Ressler, Director of the Collaboratory David Vader, and Tim Whitmoyer, who has guided efforts on correlating rubrics with ABET outcomes.

\section{Bibliography}

1. Coyle, E., Jamieson, L. and Oakes, W., "EPICS: Engineering Projects in Community Service," International Journal of Engineering Education, Vol. 21, No. 1, 2005.

2. Williams, J., "The Engineering Portfolio: Communication, Reflection, and Student Learning Outcomes Assessment," International Journal of Engineering Education, Vol. 18, No. 2, 2002, pp. 199-207.

3. Guan, Z., Lappenbush, S., Turns, J. and Yellin, J., "Portfolios in Engineering Education: What Do They Promise and How Can They Be Used?" Proceedings of the 2006 ASEE Annual Conference, Chicago.

4. King, P. and Kitchener, K., Developing Reflective Judgment, Jossey-Bass Publishers, 1994.

5. Baxter Magolda, M., Creating Contexts for Learning and Self-Authorship, Vanderbilt University Press, 1999.

6. Shuman, L., Besterfield-Sacre, M. and McGourty, J., The ABET "Professional Skills"-Can They Be Taught? Can They Be Assessed?" Journal of Engineering Education, January 2005, pp. 41-55.

7. Eliot, M. and Turns, J., "Constructing Professional Portfolios: Sense-Making and Professional Identity Development for Engineering Undergraduates," Journal of Engineering Education, Vol. 100, No. 4, pp. 630-654.

8. Dunsmore, K., Turns, J. and Yellin, J., "Looking Toward the Real World: Student Conceptions of Engineering," Journal of Engineering Education, Vol. 100, No. 2, pp. 329-348.

9. Sattler, B., Kilgore, D., and Turns, J., "I Have Never Spent Time to Think About What I Have Gained From My Projects": Linking Portfolio Development and Life-Long Learning," Proceedings of the $40^{\text {th }}$ ASEE/IEEE Frontiers in Education Conference, Washington, DC, October 2010.

10. Eris, O., "Insisting on Truth at the Expense of Conceptualization: Can Engineering Portfolios Help?" International Journal of Engineering Education, 2007.

11. McNair, L. and Garrison, W., "Portfolios to Professoriate: Helping Students Integrate Professional Identities through ePortfolios," Proceedings of the 2012 ASEE Annual Conference, San Antonio.

12. Sattler, B. and Turns, J., "Supporting Self-Authorship Development: The Contribution of Preparedness Portfolios," Proceedings of the 2012 ASEE Annual Conference, San Antonio.

13. Sattler, B., Thompson, A., Turns, J. and Kilgore, D., "The Dialectics of Goal Setting \& Monitoring: Two Students' Experiences with Portfolio Construction," Proceedings of the 2011 ASEE Annual Conference, Vancouver. 
14. Enszer, J. and Kuczenski, J., "Electronic Portfolios in Academic Advising, Self-Guided Learning, and Self-Assessment," Proceedings of the 2011 ASEE Annual Conference, Vancouver .

15. Tenenberg, J., "Using Portfolios to Tell the Design Backstory," Proceedings of the 2011 ASEE Annual Conference, Vancouver.

16. The Integrated Projects Curriculum at Messiah College, including its purposes and the role of servicelearning. 5 Apr 2013 <http://www.thecollaboratoryonline.org/wiki/Integrated_projects_curriculum>.

17. The Collaboratory at Messiah College, an overview, foundational statements, core values, program strategies and FAQs. 5 Apr 2013 <http://www.thecollaboratoryonline.org/wiki/The_Collaboratory>.

18. The Engineering GO Job Search process at Messiah College, as a means for students to join a specific project group. 5 Apr 2013< http://www.thecollaboratoryonline.org/wiki/GO_Job_Search>.

19. IPC Project Outcomes Document as used at Messiah College. 5 Apr 2013

<http://www.thecollaboratoryonline.org/wiki/IPC_Project_Outcomes_Document>.

20. The portfolio as used for IPC at Messiah College, its purpose, categories and other details for students. 5 Apr $2013<$ http://www.thecollaboratoryonline.org/wiki/Portfolio>.

21. The Logbook as used for IPC at Messiah College, inlcuding requirements, ownership, use and grading criteria. 5 Apr $2013<$ <ttp://www.thecollaboratoryonline.org/wiki/Logbook>.

22. Wang, S. and Wang H., "Organizational schemata of e-portfolios for fostering higher-order thinking," Information Systems Frontiers, Vol. 14, No. 2, pp. 395-407, April 2012.

23. Campbell, M. and Schmidt, K., "Polaris: An Undergraduate Online Portfolio System that Encourages Personal Reflection and Career Planning," International Journal of Engineering Education, No. 5, pp. 931942, 2005. 